\title{
PENGUATAN KOMPETENSI GURU DALAM PEMBELAJARAN TEMATIK SEBAGAI UPAYA OPTIMALISASI KURIKULUM 2013 DI SD KECAMATAN DELI TUA KABUPATEN DELI SERDANG
}

\author{
Faisal $^{1}{ }^{*}$, Apiek Gandamana ${ }^{1}$, Trisni Andayani ${ }^{1}$ \\ ${ }^{1}$ Universitas Negeri Medan, Medan, Indonesia \\ *Penulis Korespondensi: faisalpendas@gmail.com
}

\begin{abstract}
Abstrak
Kegiatan ini bertujuan untuk meningkatkan kompetensi guru dalam pembelajaran tematik sebagai upaya optimalisasi implementasi kurikulum 2013 di SD Kec. Deli Tua Kab. Deli Serdang. Telah diketahui bersama bahwa pembelajaran tematik merupakan salah satu amanat dari implementasi kurikulum 2013 pada jenjang SD. Oleh sebab itu, kompetensi guru dalam pembelajaran tematik mutlak diperlukan. Menyikapi hal itu, telah dilakukan pendampingan dalam rangka penguatan kompetensi guru dalam pembelajaran tematik pada jenjang SD di Kec. Deli Tua Kab. Deli Serdang. Metode pendampingan dilaksanakan melalui beberapa tahap kegiatan, antara lain: persiapan, pelaksanaan, evaluasi dan refleksi, serta tindak lanjut. Luaran yang telah dihasilkan berdasarkan program pendampingan antara lain: buku panduan pembelajaran tematik berdasarkan kurikukulum 2013 di SD dan guru model pembelajaran tematik di SD. Dengan demikian, program pendampingan yang telah dilakukan dapat meningkatkan kompetensi guru dalam pembelajaran tematik sebagai upaya optimalisasi kurikulum 2013 di SD.
\end{abstract}

Kata kunci: kompetensi guru, pembelajaran tematik, kurikulum 2013, SD

\begin{abstract}
This activity aims to improve the competence of teachers in thematic learning as an effort to optimize the implementation of the 2013 curriculum in SD Kec. Deli Tua Kab. Deli Serdang. It is well known that thematic learning is one of the mandates of the implementation of the 2013 curriculum at elementary level. Therefore, the competence of teachers in thematic learning is absolutely necessary. Responding to that, has done assistance in the context of strengthening the competence of teachers in thematic learning at elementary level in the district. Deli Tua Kab. Deli Serdang. Mentoring methods are implemented through several stages of activities, including: preparation, implementation, evaluation and reflection, and follow-up. Outcomes that have been generated based on mentoring programs include: thematic instruction manuals based on the curriculum of 2013 in elementary and teachers of thematic learning models in elementary schools. Thus, the mentoring program that has been done can improve the competence of teachers in thematic learning as an effort to optimize the 2013 curriculum in elementary school.
\end{abstract}

Keywords: teacher competence, thematic learning, curriculum 2013, elementary school

\section{PENDAHULUAN}

Kajian pembelajaran tematik adalah salah satu kajian pembelajaran di SD. Kajian ini menarik dilakukan seiring bergesernya orientasi pengkajian pembelajaran di SD karena berada pada rentangan usia dini. Pada usia tersebut seluruh aspek perkembangan kecerdasan seperti IQ, EQ, dan SQ tumbuh dan berkembang sangat luar biasa. Pada umumnya, tingkat perkembangan masih melihat segala sesuatu sebagai satu keutuhan (holistik) serta mampu memahami hubungan antara konsep secara sederhana (Fogarty, 1991). Dengan demikian, proses pembelajaran di SD masih bergantung kepada objek- objek konkrit dan pengalaman yang dialami secara langsung.

Pembelajaran tematik merupakan pendekatan pembelajaran yang memadukan berbagai kompetensi dari berbagai mata pelajaran ke dalam berbagai tema. Pembelajaran tematik adalah pembelajaran terpadu yang menggunakan tema untuk mengaitkan beberapa mata pelajaran sehingga dapat memberikan pengalaman belajar yang bermakna kepada siswa (Trianto, 2010:139). Adapun karakteristik pembelajaran tematik antara lain: (1) berpusat pada siswa, (2) memberikan pengalaman langsung, (3) pemisahan mata pelajaran tidak begitu jelas, (4) 
menyajikan konsep dari berbagai mata pelajaran, (5) bersifat fleksibel, (6) hasil pembelajaran sesuai dengan minat dan kebutuhan siswa, dan (7) menggunakan prinsip belajar sambil bermain dan menyenangkan (Rusman, 2012:258).

Saat ini, pelaksanaan proses pembelajaran tematik di SD merujuk pada amanat kurikulum 2013. Kurikulum 2013 mengamanatkan bahwa pembelajaran tematik di SD dilakukan pada setiap jenjang kelas, mulai dari kelas I hingga kelas VI. Dalam implementasinya dilakukan secara terbatas dan bertahap. Terbatas maksudnya, pembelajaran tematik kurikulum 2013 dilakukan dalam skala terbatas yang dilakukan melalui SD piloting atau SD yang menyatakan siap melaksanakan kurikulum 2013. Bertahap maksudnya, pembelajaran tematik dilakukan secara bertahap, yang dimulai dari kelas I dan IV, kelas II dan V, dan kelas III dan VI (Kemendikbud, 2013). Meskipun demikian, pemerintah saat ini mencanangkan pada tahun 2019 semua SD di Indonesia sudah melaksanakan kurikulum 2013 tanpa terkecuali (Kemendikbud, 2014).

Salah satu daerah sasaran tahap awal implementasi kurikulum 2013 adalah Kecamatan Deli Tua Kabupaten Deli Serdang. SD yang ada di Kecamatan Deli Tua melaksanakan kurikulum 2013 secara bertahap. Pada tahun ini, semua SD yang menjadi piloting pelaksanaan kurikulum 2013 di Kecamatan Deli Tua melaksanakan pembelajaran tematik di kelas I dan kelas IV. Berdasarkan informasi awal, guru-guru yang mengajar di kelas I dan kelas IV sebenarnya sudah mendapatkan pelatihan terkait dengan tata cara implementasi pembelajaran tematik pada kurikulum 2013 di SD. Akan tetapi, dalam pelaksanaannya masih banyak terdapat kekurangan dan kelemahan dalam penerapannya.

Berdasarkan hasil wawancara dan observasi di SD Negeri 104214 Deli Tua dan SD Negeri 105300 Deli Tua diperoleh fakta bahwa pembelajaran tematik kurikulum 2013 di SD belum berjalan sesuai harapan. Beberapa hal yang ditemukan antara lain: (1) pembelajaran masih menyajikan mata pelajaran secara terpisah yang menyebabkan kurang mengembangkan siswa untuk berpikir holistik dan membuat kesulitan bagi siswa, (2) di kelas I, masih terlihat adanya jadwal pelajaran terpajang di dinding ruangan kelas yang merupakan indikasi bahwa pembelajaran masih berdasarkan mata pelajaran bukan tematik, (3) di salah satu kelas I, guru mengajarkan tentang tema "Benda, Hewan, dan Tanaman di Sekitarku", tetapi sajian materi kurang terkait dengan tema itu. Hal ini merupakan indikasi bahwa dalam kegiatan awal, guru hanya memperkenalkan tema kepada siswa dan tidak membahas setiap materi sesuai tema, (4) di salah satu kelas IV, guru menyebutkan nama mata pelajaran yang akan dipelajari. Hal ini merupakan indikasi bahwa adanya perpindahan yang jelas dari satu mata pelajaran ke mata pelajaran berikutnya dan pembelajaran tidak bersifat holistik, (5) di salah satu kelas I, terlihat pergantian guru kelas dengan guru bidang studi. Guru bidang studi tidak mengaitkan pembelajaran yang dilaksanakannya dengan pembelajaran yang dilaksanakan oleh guru kelas. Hal ini, merupakan indikasi bahwa jelasnya pemisahan antar mata pelajaran, (6) dalam Rencana Pelaksanaan Pembelajaran (RPP) yang sudah dipersiapkan guru kelas, tidak ada terlihat lembar pengamatan aktivitas siswa, tetapi yang ada hanya butir-butir soal pilihan ganda dan isian yang merupakan indikasi bahwa penilaian dilakukan guru terhadap hasil pembelajaran saja, sedangkan penilaian proses tidak dilaksanakan, (7) dalam RPP yang sudah dipersiapkan guru kelas I, tidak terlihat pembagian alokasi waktu $50 \%$ untuk carlistung, seperti $15 \%$ untuk pembelajaran agama, dan $35 \%$ untuk mata pelajaran lainnya.

Paradigma pembelajaran seperti di atas, adanya indikasi bahwa amanat kurikulum 2013 tentang pembelajaran di SD yang berbasis tematik belum berjalan sesuai harapan. Menyikapi persoalan yang dikemukakan, pendampingan pembelajaran tematik dalam rangka optimalisasi implementasi kurikulum 2013 di SD mutlak diperlukan. Program pendampingan diharapkan dapat meningkatkan kompetensi guru terutama yang berkaitan dengan kemampuan merancang, melaksanakan, dan menilai secara otentik pembelajaran tematik di SD. Selain itu, akan diperoleh guru model yang dapat dijadikan contoh oleh setiap guru dalam pembelajaran tematik sebagai upaya optimalisasi implementasi kurikulum 2013 di SD. Dengan demikian, optimalisasi pembelajaran tematik dalam rangka implementasi kurikulum 2013 di SD berjalan secara efektif sesuai harapan.

\section{METODE PELAKSANAAN}

Metode pelaksanaan kegiatan dilakukan ke dalam beberapa tahap, antara lain:

\section{Persiapan}

Pada tahap persiapan, terdapat beberapa kegiatan, di antaranya: (a) sosialisasi program pengabdian kepada sekolah mitra, (b) observasi dan wawancara untuk analisis masalah, diskusi alternatif pemecahan masalah, (c) menentukan jadwal kegiatan, (d) membangun komitmen bersama dengan sekolah mitra, dan (e) menyiapkan sarana dan prasarana pendukung terlaksananya kegiatan pengabdian.

\section{Pelaksanaan}

Pada tahap pelaksanakan, dilakukan kegiatan pengabdian terkait dengan permasalahan yang dihadapi sekolah mitra, meliputi: (a) pelatihan dalam bentuk pendalaman materi tentang konsep pembelajaran tematik, (b) pelatihan dan workshop perumusan RPP, (c) pelatihan dan workshop pelaksanaan pembelajaran tematik, serta (d) pelatihan dan workshop penilaian 
otentik dalam pembelajaran tematik. Hingga pada akhirnya diperoleh guru model pembelajaran tematik di SD sesuai dengan tuntutan kurikulum 2013.

\section{Evaluasi dan Refleksi}

Tahap evaluasi dan refleksi merupakan penilaian terhadap keberhasilan program pengabdian yang telah dilaksanakan. Berdasarkan hasil evaluasi dan refleksi diperoleh gambaran terkait dengan tingkat capaian keberhasilan dan faktor kendala jika program pengabdian yang dilakukan belum berhasil sesuai dengan yang diharapkan.

\section{Tindak Lanjut}

Tindak lanjut merupakan feedback dari hasil evaluasi program pengabdian. Tindak lanjut mengarahkan keberlanjutan program atau peningkatan program yang dapat dilakukan pada masa yang akan datang. Jika program pendampingan belum berhasil, dilakukan usaha perbaikan berdasarkan telaah hasil evaluasi sebelumnya.

\subsection{Metode Pendekatan}

Metode pendekatan disesuaikan dengan permasalahan dan terget capaian setiap kegiatan. Beberapa metode yang dapat digunakan dalam pengabdian ini antara lain: pelatihan, pendampingan, simulasi, wawancara, catatan lapangan, observasi, dan kerjasama. Setiap metode diaplikasikan berdasarkan tujuan kegiatan yang ingin dicapai. Untuk lebih jelasnya, dapat dilihat pada tabel berikut.

Tabel 1. Metode Pendekatan Pelaksanaan Kegiatan

\begin{tabular}{|c|c|c|c|}
\hline No & Kegiatan & $\begin{array}{c}\text { Jenis } \\
\text { Luaran }\end{array}$ & $\begin{array}{c}\text { Metode } \\
\text { Pendekatan }\end{array}$ \\
\hline 1. & $\begin{array}{l}\text { Pelatihan } \\
\text { peningkatan } \\
\text { pemahaman } \\
\text { konsep } \\
\text { pembelajaran } \\
\text { tematik }\end{array}$ & $\begin{array}{l}\text { Buku } \\
\text { panduan } \\
\text { pembelajaran } \\
\text { tematik }\end{array}$ & $\begin{array}{l}\text { Pelatihan, } \\
\text { observasi, } \\
\text { catatan } \\
\text { lapangan, dan } \\
\text { kerja sama }\end{array}$ \\
\hline 2. & $\begin{array}{l}\text { Pelatihan dan } \\
\text { workshop } \\
\text { peningkatan } \\
\text { kemampuan } \\
\text { merumuskan } \\
\text { RPP }\end{array}$ & $\begin{array}{l}\text { Buku } \\
\text { panduan dan } \\
\text { contoh RPP }\end{array}$ & $\begin{array}{l}\text { Pelatihan, } \\
\text { pendampingan, } \\
\text { wawancara, } \\
\text { dan observasi }\end{array}$ \\
\hline 3. & $\begin{array}{l}\text { Pelatihan, } \\
\text { simulasi, dan } \\
\text { open class } \\
\text { pelaksanaan } \\
\text { pembelajaran } \\
\text { tematik }\end{array}$ & $\begin{array}{l}\text { Guru model } \\
\text { pembelajaran } \\
\text { tematik } \\
\text { dalam bentuk } \\
\text { CD }\end{array}$ & $\begin{array}{l}\text { Pelatihan, } \\
\text { pendampingan, } \\
\text { simulasi, } \\
\text { observasi, } \\
\text { wawancara, } \\
\text { catatan } \\
\text { lapangan, dan } \\
\text { kerjasama }\end{array}$ \\
\hline 4. & $\begin{array}{l}\text { Pelatihan, } \\
\text { simulasi, dan } \\
\text { open class } \\
\text { penilaian } \\
\text { otentik }\end{array}$ & $\begin{array}{l}\text { Buku } \\
\text { panduan } \\
\text { penilaian } \\
\text { otentik }\end{array}$ & $\begin{array}{l}\text { Pelatihan, } \\
\text { pendampingan, } \\
\text { simulasi, open } \\
\text { class, } \\
\text { observasi, }\end{array}$ \\
\hline
\end{tabular}

\begin{tabular}{|l|l|l|l|}
\hline $\begin{array}{l}\text { pembelajaran } \\
\text { tematik }\end{array}$ & & $\begin{array}{l}\text { wawancara, } \\
\text { catatan } \\
\text { lapangan, dan } \\
\text { kerjasama }\end{array}$ \\
\hline
\end{tabular}

\subsection{Evaluasi Pelaksanaan dan Keberlanjutan Program}

Evaluasi program dilakukan mulai dari perencanaan, pelaksanaan, dan hasil setiap kegiatan. Evaluasi yang dilakukan tidak hanya pada hasil, tetapi proses pelaksanaan kegiatan. Dengan demikian, kekurangan atau kendala yang diperoleh pada setiap pelaksanaan program dapat diidentifikasi dengan mudah dan dapat dicarikan solusi secara cepat dan tepat sesuai dengan permasalahan yang ditemukan.

Setelah masalah yang ditemukan dapat diatasi secara efektif, barulah kemudian dilaksakan program atau kegiatan selanjutnya. Hal inilah yang dikatakan dengan keberlanjutan program. Program akan berlanjut apabila satu kegiatan utama dapat diselesaikan dengan baik. Namun, jika terdapat kendala dalam melaksanakan program utama, maka program selanjutnya belum dapat dilanjutkan.

Secara sederhana proses pelaksanaan evaluasi program dan keberlanjutan program di lapangan dapat dilihat pada gamar 1 berikut.

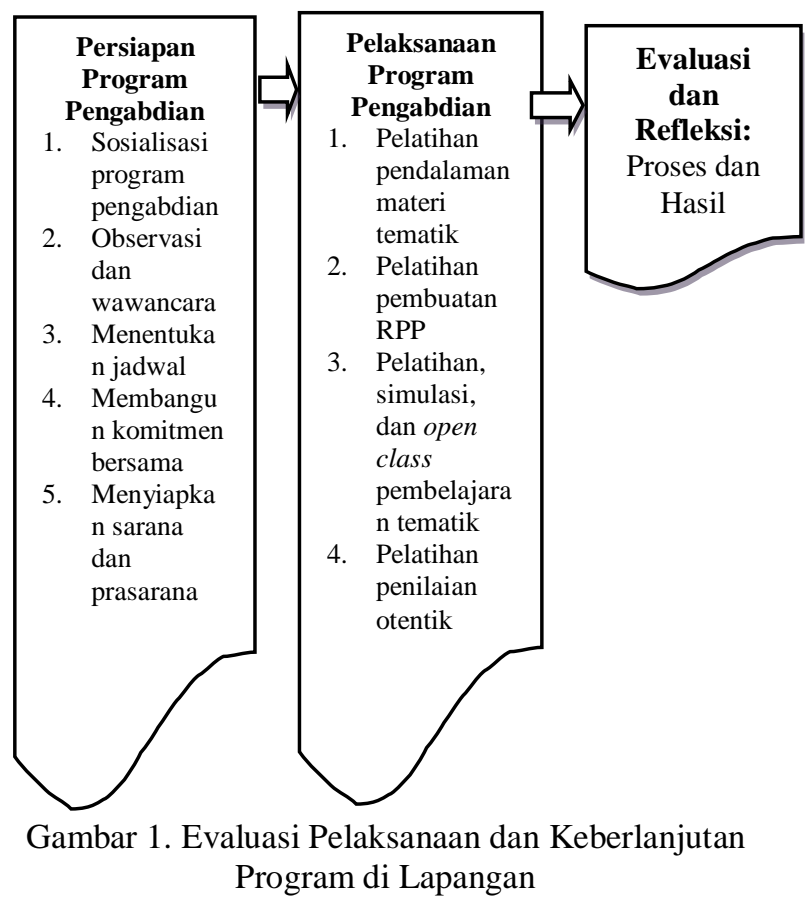

\section{HASIL DAN PEMBAHASAN}

\subsection{Hasil Kegiatan}

Program pendampingan pembelajaran tematik sebagai upaya optimalisasi implementasi kurikulum 2013 di SD Kec. Deli Tua, Kab. Deli Serdang dibagi ke dalam beberapa tahapan kegiatan sesuai dengan metode pelaksanaan kegiatan. Untuk lebih jelasnya dapat dilihat pada uraian berikut. 


\section{Persiapan}

Persiapan yang dilakukan sebelum melakukan program pendampingan pembelajaran tematik antara lain: menyiapkan slide powerpoint tentang materi pembelajaran tematik, buku panduan pembelajaran tematik, contoh RPP pembelajaran tematik, media pembelajaran tematik, dan peralatan penunjang seperti: infocus, loudspeaker, dan alat tulis.

\section{Pelaksanaan}

Program pendampingan dilaksanakan pada tanggal 3 s.d 5 Agustus 2017 di SD Negeri 104214 Deli Tua. Peserta yang hadir dalam kegiatan pengabdian ada 32 orang, terdiri dari: kepala UPT Dinas Pendidikan Kec. Deli Tua, kepala sekolah, guru, dan mahasiswa Unimed. Pelaksanaan kegiatan secara rinci dibagi ke dalam beberapa kegiatan sebagai berikut.

a. Pemaparan Materi tentang Pembelajaran Tematik

Materi yang dijelaskan terkait dengan pembelajaran tematik sebagai upaya optimalisasi implementasi kurikulum 2013 di SD antara lain: (1) ihwal kurikulum 2013, (2) hakikat pembelajaran tematik, (3) pendekatan saintifik pada kurikulum 2013, (4) pedoman pembuatan Rencana Pelaksanaan Pembelajaran (RPP) tematik sesuai kurikulum 2013, dan (5) pedoman penilaian pembelajaran tematik sesuai tuntutan kurikulum 2013 di SD.

Berdasarkan paparan materi yang telah dijelaskan di atas, para peserta dapat memahami secara jelas terkait dengan pembelajaran tematik sesuai tuntutan kurikulum 2013 di SD. Para guru telah memahami kurikulum 2013 di SD, hakikat pembelajaran tematik, dan pendekatan saintfik pada kurikulum 2013. Selanjutnya, para guru juga telah dapat merancang RPP tematik dan melaksanakan penilaian otentik sesuai dengan tuntutan kurikulum 2013 di SD. Secara sederhana, kegiatan pemaparan materi dapat dilihat pada gambar berikut.

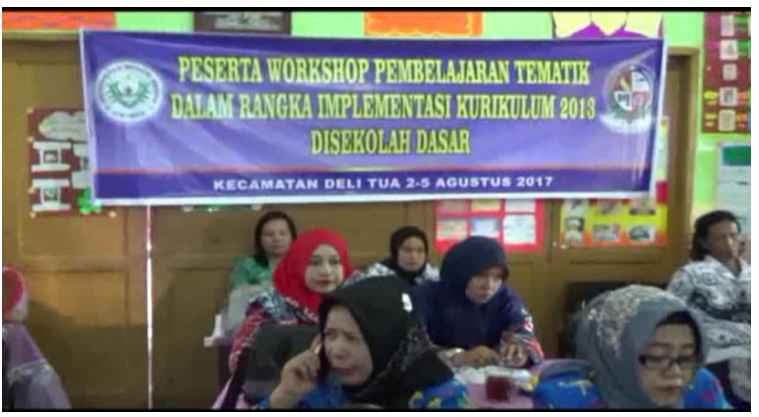

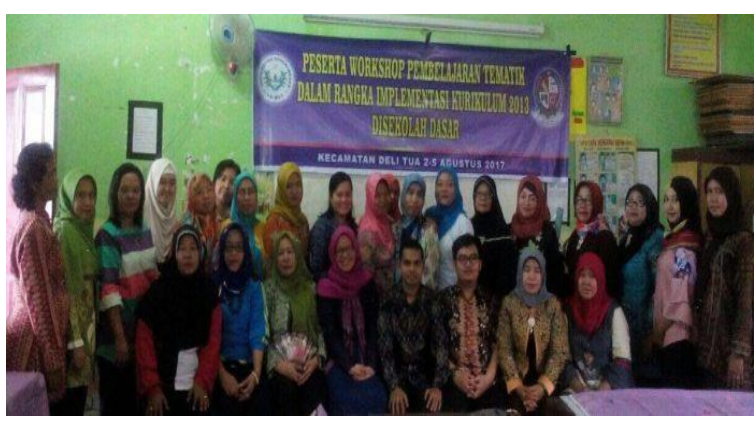
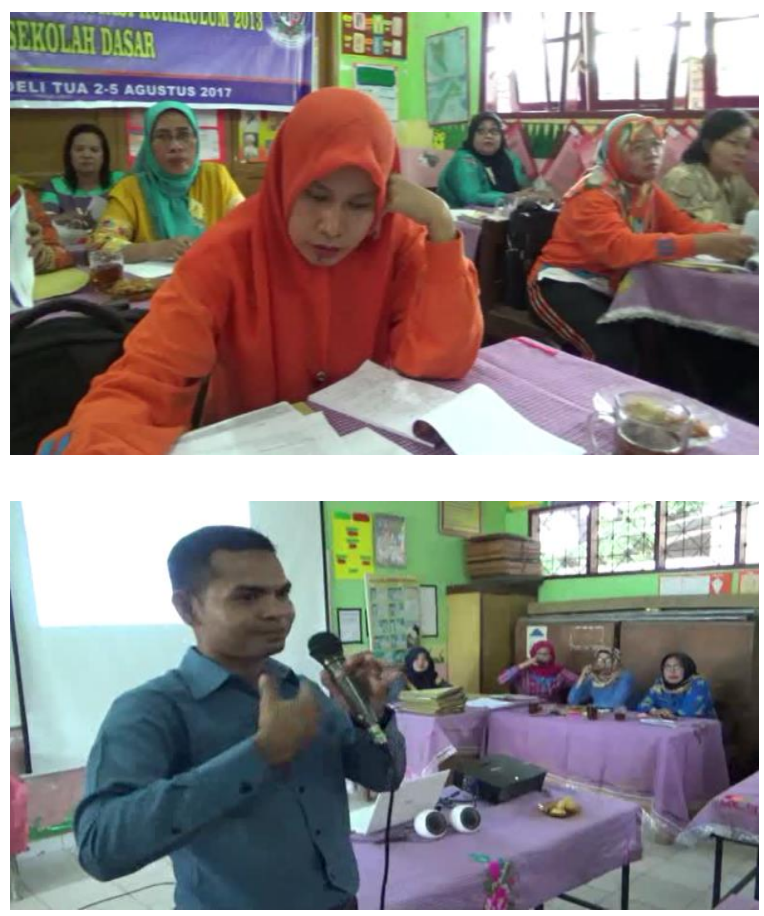

Gambar 2. Pemaparan Materi Pembelajaran Tematik dalam Kurikulum 2013 di SD

\section{b. Simulasi Pembelajaran Tematik}

Simulasi pembelajaran tematik dilakukan pada hari ke dua program pendampingan. Simulasi pembelajaran tematik dilakukan bertujuan untuk melihat sejauh mana penguasaan dan kemampuan guru dalam melaksanakan pembelajaran tematik di kelas. Para guru diminta tampil bersimulasi di depan teman sejawat seolah-olah berhadapan langsung dengan siswa SD. Melalui simulasi yang dilakukan, para peserta memperoleh masukan dan saran yang sangat berharga dalam meningkatkan kemampuan mengajar untuk tahap selanjutnya. Secara garis besar, kegiatan simulasi berhasil dilakukan. Berdasarkan pengamatan, para guru telah dapat melaksanakan proses pembelajaran tematik secara efektif meskipun masih ada kekurangan. Secara sederhana, kegiatan simulasi dapat dilihat pada gambar 3 berikut. 

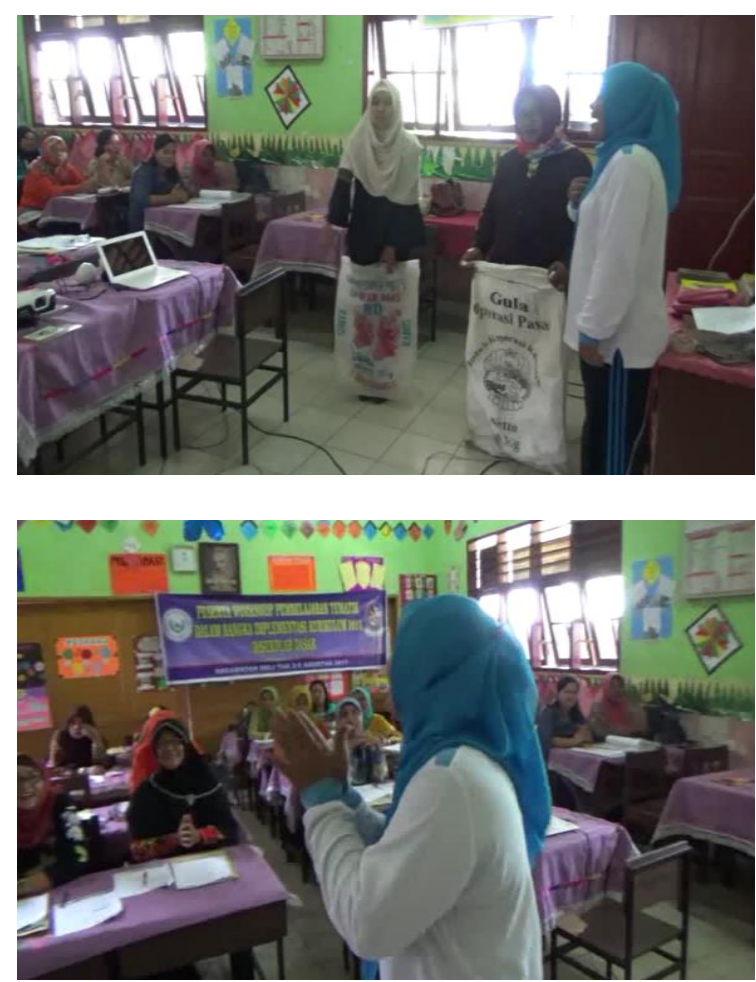

Gambar 3. Simulasi Pembelajaran Tematik

\section{c. Open Class}

Open class dilaksanakan di 8 (delapan) SD yang ada di Kecamatan Deli Tua Kabupaten Deli Serdang. Kegiatan Open class didokumentasikan sebagai guru model pembelajaran tematik dalam rangka kurikulum 2013 di SD. Pada kegiatan open class diamati tingkat keterlaksanaan proses pembelajaran tematik dan penilaian otentik. Dengan demikian, akan diperoleh dampak kegiatan program pendampingan terutama dalam hal penguatan kompetensi guru dalam pembelajaran tematik sebagai upaya optimalisasi pembelajaran tematik di SD.

Secara sederhana, gambaran implementasi open class di beberapa SD Kecamatan Deli Tua Kabupaten Deli Serdang dapat dilihat pada gambar 4 berikut.

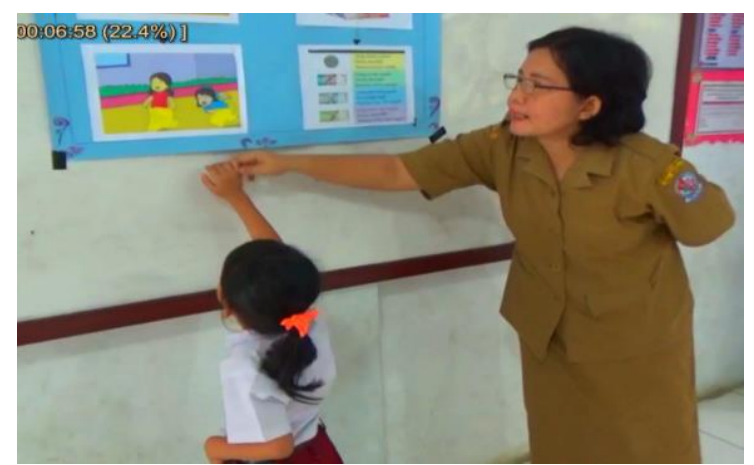

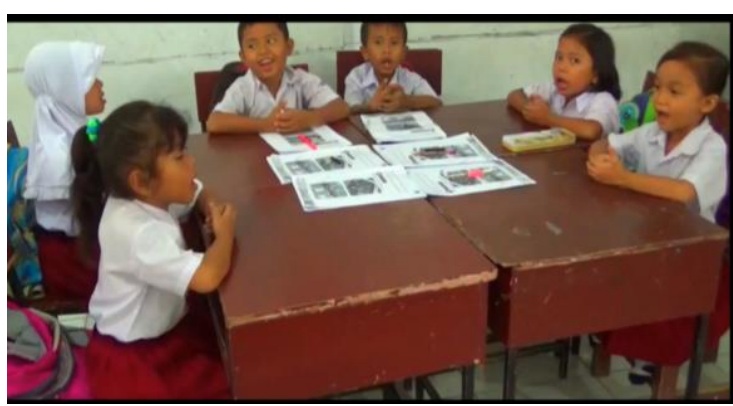
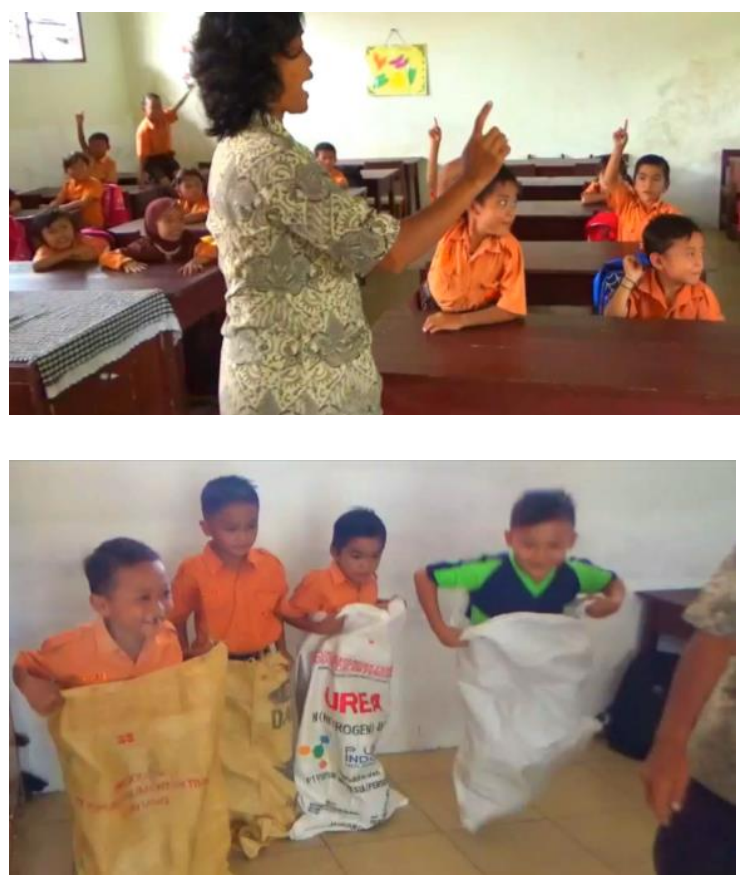

Gambar 4. Kegiatan Open Class Program Pengabdian

\section{Evaluasi dan Refleksi}

Telah dijelaskan sebelumnya pada metode pelaksanaan kegiatan, bahwa tahap evaluasi dan refleksi merupakan penilaian terhadap keberhasilan program pengabdian yang telah dilaksanakan. Berdasarkan hasil evaluasi dan refleksi diperoleh gambaran terkait dengan tingkat capaian keberhasilan dan faktor kendala jika program pengabdian yang dilakukan belum berhasil sesuai dengan yang diharapkan. Berdasarkan observasi dan analisis, tingkat keberhasilan program pengabdian dapat dijabarkan seperti pada tabel 2 berikut.

Tabel 2. Tingkat Keberhasilan Program Pengabdian

\begin{tabular}{|c|l|c|c|}
\hline No & Kegiatan & $\begin{array}{c}\text { Persentase } \\
\text { Keberhasilan }\end{array}$ & Kualifikasi \\
\hline 1 & $\begin{array}{l}\text { Pemaparan } \\
\text { Materi } \\
\text { Pembelajaran } \\
\text { Tematik }\end{array}$ & $85 \%$ & $\begin{array}{c}\text { Sangat } \\
\text { Baik }\end{array}$ \\
\hline 2 & $\begin{array}{l}\text { Simulasi } \\
\text { Pembelajaran } \\
\text { Tematik }\end{array}$ & $82 \%$ & $\begin{array}{c}\text { Sangat } \\
\text { Baik }\end{array}$ \\
\hline 3 & Open Class & $83 \%$ & $\begin{array}{c}\text { Sangat } \\
\text { Baik }\end{array}$ \\
\hline
\end{tabular}


Berdasarkan tabel 2 di atas, diperoleh gambaran tingkat keberhasilan program pengabdian pada gambar 5 berikut.

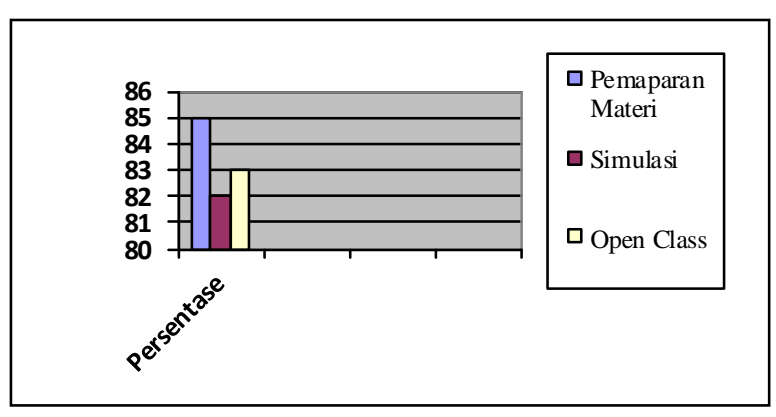

Gambar 5. Tingkat Keberhasilan program Pengabdian

Meskipun tingkat keberhasilan program pengabdian berada pada kategori Sangat Baik (SB), terdapat beberapa kendala yang diperoleh berdasarkan program pengabdian, di antaranya:

a. Guru kurang mampu menerapkan pendekatan saintifik pada pembelajaran tematik. Hal ini terlihat dari kegiatan open class, di mana para guru sering terlupa pada tahapan menanya. Berdasarkan observasi, masih ada beberapa guru yang belum melaksanakan kegiatan menanya pada langkah pendekatan saintifik yang digunakan.

b. Guru kurang maksimal dalam memanfaatkan media pembelajaran. Hal ini terlihat dari sedikitnya penggalian informasi dari media yang dikembangkan. Padahal, media yang telah dikembangkan sangat baik dan mengandung banyak informasi yang dapat digali.

c. Penilaian otentik belum maksimal dilaksanakan. Penilaian yang dilakukan masih berorientasi pada hasil, kurang melibatkan proses sehingga kurang dirasakan perolehan hasil secara komprehensif tentang kompetensi siswa.

\section{Tindak Lanjut}

Tindak lanjut merupakan feedback dari hasil evaluasi program pengabdian. Tindak lanjut mengarahkan keberlanjutan program atau peningkatan program yang dapat dilakukan pada masa yang akan datang. Berdasarkan hasil evaluasi dan refleksi perlu dilakukan tindak lanjut sebagai berikut.

a. Pendampingan berkelanjutan tentang pengintegrasian model pembelajaran inovatif pada pembelajaran tematik di SD.

b. Pendampingan berkelanjutan tentang pemanfaatan media pembelajaran dalam pembelajaran tematik di SD.

c. Pendampingan berkelanjutan tentang penilaian otentik berbasis proses dalam pembelajaran tematik di SD.

Berdasarkan paparan di atas, program pendampingan berkelanjutan diharapkan dapat menjadikan SD yang ada di Kec. Deli Tua Kab. Deli Serdang menjadi sekolah binaan berkelanjutan LPM Unimed sebagai upaya meningkatkan kompetensi guru dalam pembelajaran tematik sesuai tuntutan kurikulum 2013 di SD.

\subsection{Pembahasan}

Menurut Firman (2000:56), keberhasilan sebuah program ditandai dengan ciri-ciri sebagai berikut: (a) berhasil mengantarkan peserta mencapai tujuantujuan instruksional yang telah ditetapkan, (b) memberikan pengalaman belajar yang atraktif, melibatkan peserta secara aktif sehingga menunjang pencapaian tujuan instruksional, dan (c) memiliki sarana-sarana yang menunjang proses pembelajaran. Selain itu, dijelaskan juga bahwa keberhasilan program ditandai dengan persentase keberhasilan minimal $\geq 75 \%$ pada kategori baik.

Mengacu pada pendapat di atas, keberhasilan program pengabdian dapat dijabarkan sebagai berikut.

1. Pemaparan Materi Pembelajaran Tematik Tingkat keberhasilan program pengabdian pada kegiatan pemaparan materi pembelajaran tematik mencapai $85 \%$ dengan kategori Sangat Baik (SB). Artinya, 85\% tujuan instruksional yang ditetapkan tentang materi pembelajaran meliputi: (a) ihwal kurikulum 2013, (b) hakikat pembelajaran tematik, (c) pendekatan saintifik pada kurikulum 2013, (d) pedoman pembuatan Rencana Pelaksanaan Pembelajaran (RPP) tematik sesuai kurikulum 2013, dan (e) pedoman penilaian pembelajaran tematik sesuai tuntutan kurikulum 2013 di SD dapat dipahami dengan baik oleh peserta.

\section{Simulasi Pembelajaran Tematik}

Tingkat keberhasilan program pengabdian pada kegiatan simulasi pembelajaran mencapai $82 \%$ dengan kategori Sangat Baik (SB). Artinya, pelaksanaan simulasi pembelajaran sudah mencerminkan pembelajaran tematik sesuai dengan tuntutan kurikulum 2013 di SD. Dengan demikian, dapat disimpulkan bahwa pelaksanaan simulasi pembelajaran berjalan secara efektif sesuai dengan yang diharapkan.

\section{Open Class}

Tingkat keberhasilan program pengabdian pada kegiatan open class mencapai $83 \%$ dengan kategori Sangat Baik (SB). Artinya, program pengabdian yang dilaksnakan pada kegiatan open class sudah berjalan secara efektif. Sebagian besar guru telah melaksanakan proses pembelajaran tematik di kelas sesuai dengan tuntutan implementasi kurikulum di SD.

\section{Luaran yang Dihasilkan}

Luaran yang dihasilkan berdasarkan program pengabdian yang dilakukan dapat dijabarkan sebagai berikut. 
1. Buku panduan pembelajaran tematik berdasarkan kurikulum 2013 di SD yang berisi: (1) ihwal kurikulum 2013, (2) hakikat pembelajaran tematik di SD, (3) panduan penyusunan dan contoh RPP tematik, dan (4) pedoman penilaian otentik dalam pembelajaran tematik. Secara sederhana, buku panduan pembelajaran tematik dapat dilihat pada gambar 6 berikut.

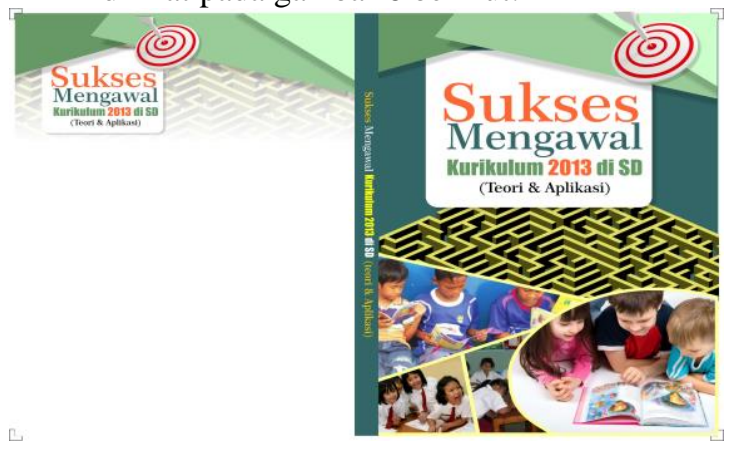

PGSD FIP UNIMED iii

DAFTAR ISI

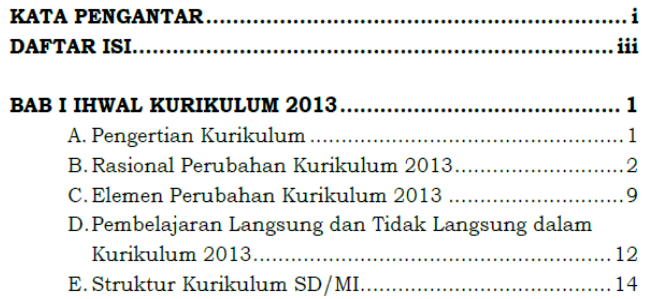

Gambar 6. Buku Panduan Pembelajaran Tematik di SD

2. Guru model pembelajaran tematik di SD yang tergambar melalui video pembelajaran sehingga dapat dijadikan acuan bagi guruguru yang lain. Secara sederhana, video pembelajaran guru model dapat dilihat pada gambar 7 berikut.

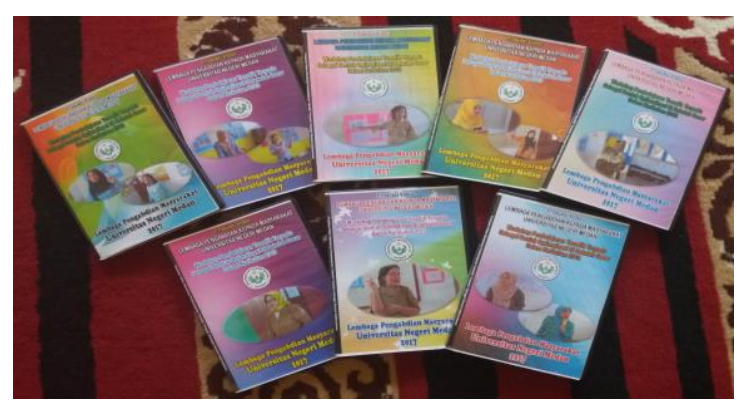

Gambar 7. Video Guru Model Pembelajaran Tematik di SD

3. Artikel ilmiah yang dipublikasikan pada jurnal nasional ber-ISSN Online.

\section{SIMPULAN}

Program pendampingan dalam bentuk penguatan kompetensi guru dalam pembelajaran tematik sebagai upaya optimalisasi implementasi kurikulum 2013 di SD telah berhasil dilakukan secara efektif. Hal ini tergambar dari meningkatnya pemahaman guru tentang pembelajaran dan dihasilkannya guru model tentang pelaksanaan pembelajaran tematik sesuai dengan tuntutan kurikulum 2013 di SD. Meskipun demikian, masih terdapat beberapa kekurangan berdasarkan program pengabdian yang dilakukan terutama dalam hal pengintegrasian pendekatan saintifik pada pembelajaran tematik, optimalisasi pemanfaatan media, dan penilaian otentik berbasis proses. Dengan demikian, masih diperlukan pendampingan berkelanjutan sebagai upaya penguatan kompetensi guru dalam pembelajaran tematik sesuai tuntutan kurikulum 2013 pada masa yang akan datang.

\section{DAFTAR PUSTAKA}

Firman, Harry. 2000. Penilaian Hasil Belajar dalam Pengajaran. Bandung: FMIPA UPI.

Fogarty. 1991. How to Integrate the Curricula. New York: Skylight Publishing, Inc.

Kemendikbud. 2013. Materi Pelatihan Implementasi Kurikulum 2013. Jakarta: Badan Pengembangan Sumber Daya Manusia dan Kebudayaan dan Penjaminan Mutu Pendidikan-Kemendikbud.

Kemendikbud. 2014. Materi Pendampingan Kurikulum 2013. Jakarta: Badan Pengembangan Sumber Daya Manusia dan Kebudayaan dan Penjaminan Mutu Pendidikan.

Rusman. 2010. Model-Model Pembelajaran Mengembangkan Profesional Guru. Jakarta: Rajawali Pers.

Trianto. 2010. Model Pembelajaran Terpadu. Jakarta: Kencana Prenada Group. 